\title{
Electronic Employment Record Book Introduction: Legal Perspective (Experience of the Russian Federation)
}

By

\author{
Dr. Andrey V. Egorov \\ Dean of the Faculty of Law - Volgograd \\ Institute of Management, branch of Russian \\ Presidential Academy of National Economy \\ and Public Administration \\ Volgograd, Russian Federation \\ Correspondence: decanurf@vlgr.ranepa.ru
}

Dr. Sherif Youssef Khater

Mansoura, Egypt Dean of Faculty of Law - Mansoura University

Correspondence:lawfac@mans.edu.eg

\section{Dr. Ekaterina V. Stepanova}

Associate Professor of Linguistics, PhD in Linguistics

Volgograd Institute of Management, branch of Russian Presidential Academy of National Economy and Public Administration Volgograd, Russia,

Correspondence: stepanova.volg@mail.ru 


\begin{abstract}
In 2020, the legislation of the Russian Federation has undergone global changes due to introduction of electronic employment record book system about the employees' labor activity with a simultaneous gradual abandonment of hard form. The paper analyzes key provisions of normative informatization regulation of Employment Record Book System, which will contribute to reducing bureaucratic costs of employers simplifying confirmation procedure of labor seniority and experience. The Pension Fund of the Russian Federation was appointed responsible for data collection and has been introducing for several years a Pension Insurance Record System which calculates accordingly retirement benefits of an employee. There are grounds to consider that successful Russian experience could be quite beneficial for other developing countries. Similarly, on the Russian internet portal Gosuslugi providing every registered citizen with opportunity to receive necessary public services in a few clicks within a few minutes, there are option of getting pension insurance data certified by an electronic digital signature. Similar digital algorithms are introduced into electronic employment record book system which legal aspects will be studied in the paper.
\end{abstract}

Key terms: Electronic Employment Record Book, seniority, digital employment data, employment contract, employee. 


\section{Introduction}

The Russian Federation has accumulated extensive experience in documentary employment record keeping on the labor activity of workers associated with the use of different technologies and methods. For almost a century, the working citizens use such a form of document as an employment record book of a standard form which is initially, according to the previous legislation of the Russian Soviet Federative Socialist Republic and later according to the legislation of the Russian Federation, is the main document on labor activity and work experience of an employee.

If we talk about international experience, then almost all European countries abandoned the use of paper "labor" in the late XX century. In Spain, the Vida Laboral electronic system records history of employment, dismissals, status of tax deductions of an employee, automatically transferring to the Ministry of Labor and the Social Insurance Fund.

However, in most Western countries, including the United States, there are no special electronic systems that record employment data. Instead of employment record keeping books, employers require applicants to submit a resume, a diploma of 
education, and characteristics from their previous place of work. In case of distrust of the information indicated there, the security service is engaged in the search for information about a potential employee.

Employment history is recorded in the tax authorities based on deductions. For calculating pensions, personal accounts of citizens are used, which also contain information about employers, salaries received and the amount of contributions. Every year, an employee receives reports from his pension fund on the size of his pension savings and what kind of pension he expects in the future.

Despite the obvious advantages of employment record book in hard form, it should be noted that documentary employment record keeping technologies open new opportunities for all parties to social and labor relations. Digitalization has changed the nature and organization and use of hired labour [Lushnikov, Lushnikova, 2009, p.848]. For employees, access to information about their work is simplified, and the level of protection of such data is increased. The fact is that in practice, up to now, there have been cases of loss of documents on labor activity, which is associated with the need in some cases to prove various circumstances related to labor relations (see, for example, Decision № 2-5190/2016 25190/2016 M-5515/2016 M-5515/2016 dated November 28, 2016 
in case № 2-5190/2016, Decision of the Soviet District Court of Astrakhan on June 21, 2013 in case № 2-1758/2013, etc.) For employers, costs associated with the need to maintain large personnel services responsible for documenting labor relations will be reduced in the future. The interest of the State is associated with the need to reduce the number of disputes about seniority, increase the level of certainty of legal consequences within the framework of the dynamics of labor relations, and combat the practice of illegal or hidden labor relations.

\section{Materials and methods}

The mutual trilateral interest of employees, employers and the state objectively predetermined the relevant legislative and organizational changes. For several years, preparatory procedures, public discussions were conducted, and as a result, on December 16, 2019, Federal Law No. 439-Ф3 [Explanatory note to the bill "On Amendments to the Labor Code of the Russian Federation regarding the generation of information on labor activity in electronic form", 2019] amended the Labor Code of the Russian Federation (hereinafter the Labor Code of the Russian Federation) that established the rules for generating information on labor activity in digital form introducing the so-called Digital Employment Record Book that do not have a physical hard 
medium. The amendments proposed by the bill affect about 60 million employees and 8.4 million business entities in Russia [Labor Code of the Russian Federation, 2001, 2002]. It is the responsibility of employers to compile in electronic form the basic information on labor activity and seniority for each employee working including part-time employment. By default, this includes information about the employee, his place of work, his labor function, the employee's transfer to another permanent job, the dismissal of the employee indicating the reason and grounds for the termination of the employment contract.

The legal aspects of the introduction of the new system involve a transition period during which employers must organize interaction with the authorized body which is the Pension Fund of the Russian Federation and provide information about their employees in cases of hiring, transferring to another permanent job and dismissal, applying for continued employment by the employment record book in accordance with Article 66 of the Labor Code of the Russian Federation or on the provision of information on labor activities in accordance with Article 66.1 of the Labor Code of the Russian Federation (see Federal Law of December 16, 2 019, No. 436-FZ [Federal Law No. 436- FZ, 2019]). Information is submitted from January 1, 2020 no later than 
the 15th day of the month following the month in which there were cases of hiring, transfers to another permanent job and dismissal. When submitting the specified information for the first time in relation to the employee, information is simultaneously presented on his labor activity as of January 1, 2020 with the given employer. At the same time, from January 1, 2021, when transferring to another permanent job, submitting an application to continue maintaining the workbook in accordance with article 66 of the Labor Code of the Russian Federation, or to provide him with information about labor activities in accordance with article 66.1 of the Labor Code of the Russian Federation - such information is provided no later than the 15th day of the month following the month in which the transfer to another permanent job or the submission of the relevant application took place; and in cases of hiring and dismissing an employee - no later than the working day following the day of issuing the relevant order, other decisions or documents confirming the registration of the employment relationship. An employer, if the number of employees for the previous reporting period - a month is 25 or more persons, is required to submit information in the form of an electronic document signed by an enhanced qualified electronic signature (see 
Federal Law No. 63-FZ dated April 6, 2011 "On electronic signature "[Federal law, 63-FZ, 2011]).

Labor activity data processing in digital form is carried out by the employer using software and hardware tools to automate his activities, or using an electronic service provided free of charge by the Pension Fund of the Russian Federation. It should be noted here that for employers who are not connected to electronic document management, the Pension Fund of the Russian Federation is developing the service "Policyholder's Office" for reporting in electronic form. However, in order to use this service to send documents, the employer will need to issue an enhanced qualified electronic signature [For employers about the digital employment record book, 2020]. It should be noted that information on labor activity, which constitutes a National Security Information in accordance with the legislation of the Russian Federation, and documents containing such information, are not subject to submission to the bodies of the Russian Pension Fund (RPF).

\section{Results and Discussion}

Information on labor activity is stored in the information resources of the FIU. Automated information system RPF (hereinafter also referred to as AIDS of RPF) is an organizational 
and technological system consisting of a set of automation tools (software and technology complexes) and personnel. Software and technology complexes are designed to automate the activities of the fund, reduce the level of "manual labor", increase the speed of providing public services to citizens and provide information to other authorities, which is used to provide them with state and municipal services. The goal of creating AIDS of RPF is to create a multi-level unified information space and process management system that guarantees the effective implementation of all functions assigned to the RPF. When creating the AIDS of RPF, the most important priority is ensuring information security and protecting personal data of citizens. A lot of work has been done to create a unified technological platform based on modern architecture and an effective information security system, a high level of labor automation. Importantly, the operation of the AIDS of RPF precludes an increase in the staff of the Pension Fund of the Russian Federation [About the Automated Information System of the Pension Fund, 2020].

Thus, at present, as a general rule, an alternative is being established for a person entering the work who is entitled to present to the employer information about the labor activity together with or instead of the employment record book (Prostov, Popova, 
Stepanova, 2019). Since 2021, exclusively compulsory electronic format for providing information by the employer for persons starting their labor activity is established.

The issues of a person's access to information about his or her labor activity are regulated separately. Art. 66.1 of the Labor Code of the Russian Federation provides several opportunities for access:

- at the employer at the previous place of work (for the period of work for the employer) on paper, duly certified, or in the form of an electronic document signed by an enhanced encrypted and certified digital signature (if the employer has one);

- in a multifunctional center for the provision of state and municipal services in hard form duly certified;

- in the Pension Fund of the Russian Federation on paper, duly certified or in the form of an electronic document signed by an enhanced qualified electronic signature;

- using a single portal of state and municipal services in the form of an electronic document signed by an enhanced qualified electronic signature.

The employer is obligated to provide the employee (except if the employee is kept a work book) information about the labor 
activity for the period of work with the given employer in the manner specified in the application of the employee (on paper, duly certified, or in the form of an electronic document signed enhanced qualified electronic signature (if available to the employer)) submitted in writing or sent in the manner established by the employer to the electronic address employer mail: during the period of work no later than three business days from the date of submission of this application; upon dismissal on the day of termination of the employment contract.

If an employee identifies incorrect or incomplete information in the information on labor activities submitted by the employer for storage in the information resources of the Pension Fund of the Russian Federation, the employer, upon written request from the employee, is obliged to correct or supplement the information on labor activity and submit it to the AIDS of RPF.

At the local level of normative regulation of labor relations (at the level of the employer) it is supposed in accordance with Art. 8 of the Labor Code of the Russian Federation, the adoption or amendment of local regulations taking into account the views of the elected body of the primary trade union organization (if any); if employers have collective-contractual regulation, preparing and discussing with authorized representatives of employees changes 
within the framework of collective bargaining (Article 36 of the Labor Code of the Russian Federation); ensuring technical readiness for the submission of information on labor activities for storage in the AIDS of RPF; a notice by June 30, 2020 of each employee in writing about changes in labor legislation related to the generation of information on labor activity in electronic form, as well as about the employee's right, before 31 December 2020, to submit to the employer a written statement about the choice between continuing to keep the employer in the work book in in a documentary form or by providing the employer with information about labor activity in electronic form. The employer continues to keep his workbook in documentary form in the absence of the will of the employee, however, in the future, the right to the electronic form is retained with subsequent employment. If the employee expressed a desire to use the electronic form, the employer gives him the workbook in his hands and is relieved of responsibility for its maintenance and storage (when issuing the workbook, an appropriate entry is made in it).

\section{Conclusions}

The forms in which the provision of information on labor activity is provided are approved by Order of the Ministry of Labor of Russia dated 01.20.2020 No. 23n [Order of the Ministry of 
Labor and Social Protection of the Russian Federation of January 20, 2020 No. 23n]. Information is generated on the basis of orders (orders), other decisions or documents confirming the registration of labor relations between the employer and the employee and contains data on the employee's labor activity, his hiring, transfers to another permanent job and dismissal (the so-called personnel measures ) The analysis of the approved forms showed that the information on the digital employment record book will include:

- information about the employee;

- dates of admission, dismissal, transfer to another job;

- place of employment;

- type of event (reception, transfer, dismissal);

- position, profession, specialty, qualification, structural unit;

- type of work entrusted;

- the basis of the staffing event (date, number and type of document);

- reasons for termination of the employment contract.

The potential risks of introducing a new format include the fact that the transition period involves additional organizational costs, since employers will need to report to the Pension Fund of 
the Russian Federation on new forms, record information in both forms of work books, and fulfill all applicable labor storage and management requirements books.

However, in accordance with Art. 65 of the Labor Code, when concluding an employment contract, an employee must provide, among other documents, a work book (unless it is the first time he is employed) - this gives the employer the opportunity to check whether the stated work experience matches the actual one.

In the absence of an employment record book, it will be possible to verify this independently only after the employee has been employed [Poluboyarov, 2020].

However, in our opinion, in this case, the existing difficulties can be overcome by making appropriate amendments to the Labor Code of the Russian Federation by regulating the issues of providing the employer access to the person's electronic workbook at the stage of employment. 


\section{References}

1. About the Automated Information System of the Pension Fund URL: http://www.pfrf.ru/press_center 2015/02/11/84903 (accessed 13 March 2020).

2. Anisimov, A.P., Eliseev, V.S., Stepanova, E.V., 2018, Revisiting the issue of unitary enterprises' "Inefficiency" (On the example of the stavropol territory), $2018 \quad$ Law and Economics Yearly Review 7, p. 351-364.

3. Buletova N.E., Zlochevsky I.A., Stepanova E.V., 2017. Structural analysis and criteria for assessment of state economic policy// International Journal of Applied Engineering Research. 2017. Vol. 12. № 17. P. 6603-6614

4. Explanatory note to the bill "On Amendments to the Labor Code of the Russian Federation regarding the generation of information on labor activity in electronic form" URL: https://sozd.duma.gov.ru/bill/748684-7 (accessed 13 March 2020).

5. Federal law of April 6, 2011 No. 63-FZ "On electronic signature" // Collection of laws of the Russian Federation of April 11, 2011 No. 15 of Art. 2036. 
6. Federal Law of December 16, 2019 No. 436-FZ "On Amending the Federal Law" On Individual (Personified) Accounting in the Compulsory Pension Insurance System "//" Official Internet Legal Information Portal "(www.pravo.gov.ru) December 16, 2019 // Meeting of the legislation of the Russian Federation of December 23, 2019 No. 51 (Part I), Article 7488.

7. Federal Law of December 16, 2019 No. 439-FZ "On Amendments to the Labor Code of the Russian Federation regarding the generation of information on labor activity in electronic form" // Official Internet portal of legal information. URL: http://www.pravo.gov.ru (accessed 13 March 2020).

8. For employers about the electronic workbook URL: http://www.pfrf.ru/branches/tver/news 2020/01/13/197401 (accessed 13 March 2020).

9. Labor Code of the Russian Federation dated December 30, 2001 No. 197-FZ (as amended and supplemented) // Collection of legislation of the Russian Federation dated January 7, 2002 No. 1 (Part I), Art. 3. 
10. Lushnikov A.M., Lushnikova M.V., 2009. Labor law course. Textbook. Volume 1. Publishing House "Statute". Moscow.

11. Order of the Ministry of Labor and Social Protection of the Russian Federation of January 20, 2020 No. 23n "On approval of the form of information on labor activity provided to the employee by the employer, the form of providing information on labor activity from the information resources of the Pension Fund of the Russian Federation and the procedure for filling them" // "The Official Internet Portal of Legal Information" February 25, 2020. URL: www.pravo.gov.ru (accessed 13 March 2020).

12. Poluboyarov E., 2020. Five main risks of accelerated transition to electronic workbooks URL: https: // www.garant.ru/ia/opinion/author/poluboyarov/1281989 (accessed 13 March 2020).

13. Prostov A.V., Popova, O.I., Stepanova, E.V., 2019, Translators Training for Joint Venture Employment (Conference Paper) // IOP Conference Series: Materials Science and Engineering, 483 (1), DOI: 10.1088/1757899X/483/1/012012. 